\title{
OPTIMASI MEDIUM PERBANYAKAN IN VITRO TUNAS TALAS KALIURANG (Colocasia esculenta L.) DIPLOID DAN TETRAPLOID
}

\section{Optimation of In Vitro Shoot Proliferation Medium for Diploid and Tetraploid Kaliurang Taro (Colocasia esculenta L.)}

\author{
Khalisa Aini Sinaga ${ }^{1}$, Dyah Retno Wulandari ${ }^{2 \star}$, Diah Ratnadewi ${ }^{3}$ \\ ${ }^{1}$ Program Studi Biologi Tumbuhan, IPB University, JI. Agatis, Kampus IPB Dramaga, Bogor, 16680 \\ ${ }^{2}$ Pusat Penelitian Bioteknologi, Lembaga Ilmu Pengetahuan Indonesia, Jalan Raya Bogor Km 46 Cibinong, 16911 \\ ${ }^{3}$ Dept. Biologi, Fak. Matematika dan Ilmu Pengatuan Alam, IPB University, Jl. Agatis, Kampus IPB Dramaga, Bogor, 16680 \\ *Email: dyahwulandari@yahoo.com
}

\begin{abstract}
Taro cv. Kaliurang has a good taste and is tolerant to certain pests and diseases but its development is hampered by insufficient number of good quality plant materials. Quality improvement has been carried out through polyploidization. Shoot multiplication is an important step in micropropagation, which often needs specific formulation of culture medium. This study aimed to obtain an optimum formulation of in vitro shoot-inducing medium of taro $\mathrm{cv}$. Kaliurang. Explants from one diploid and three tretraploid clones were subjected to six treatments of medium formulations with various concentrations of thiamine and adenine in BAP-containing MS media. Shoots were then rooted, followed by plantlet acclimatization. Ploidy level was measured using flow cytrometry. The rooting medium was $1 / 2$ MS without growth hormones, whereas acclimatization medium was a mixture of sterile soil, husk, and cocopeat. The results showed that $M S+2 \mathrm{mg} \mathrm{L}^{-1} B A P+4 \mathrm{mg} \mathrm{L}^{-1}$ thiamine $+2 \mathrm{mg} \mathrm{L}^{-1}$ adenine was the optimum medium with an average 3.45 shoots per explant. Plantlet acclimatization was successful with $99.1 \%$ survival. Flow cytometry measurement confirmed tetraploidy level of the regenerants from 3 tetraploid clones.
\end{abstract}

Keywords: adenine, acclimatization, benzyl amino purine, shoot proliferation, thiamine

\begin{abstract}
ABSTRAK
Talas Kaliurang memiliki rasa yang enak dan toleran terhadap hama dan penyakit tertentu, namun pengembangannya terkendala oleh ketercukupan benih bermutu. Upaya perbaikan mutu tanaman telah dilakukan sebelumnya melalui poliploidisasi. Perbanyakan tunas merupakan langkah penting, yang membutuhkan formula spesifik untuk media kultur. Penelitian ini bertujuan untuk mengoptimasi medium perbanyakan tunas in vitro dari satu klon diploid dan tiga klon tetraploid, yang dikulturkan pada enam konsentrasi tiamin dan adenin dalam media MS yang mengandung BAP. Tunas kemudian diinduksi akar, lalu diaklimatisasi, dan pengukuran tingkat ploidi menggunakan flow cytometry. Media pengakaran adalah $1 / 2 \mathrm{MS}$ tanpa ZPT, media aklimatisasi adalah campuran tanah steril, sekam dan kokopit. Hasil penelitian ini menunjukkan bahwa medium MS $+2 \mathrm{mg} \mathrm{L}^{-1} \mathrm{BAP}+4 \mathrm{mg} \mathrm{L}^{-1}$ tiamin $+2 \mathrm{mg} \mathrm{L}^{-1}$ adenin merupakan medium optimum dengan rata-rata 3,45 tunas per-eksplan. Hasil aklimatisasi menunjukkan bahwa 99,1\% tanaman dapat bertahan hidup. Analisis ploidi dengan flow cytometry menunjukkan bahwa tanaman hasil regenerasi tunas talas Kaliurang tetraploid memiliki tingkat ploidi yang stabil.
\end{abstract}

Kata Kunci: adenin, aklimatisasi, benzilamino purin, tiamin, proliferasi tunas 


\section{PENDAHULUAN}

Salah satu upaya yang dapat dilakukan untuk mencapai ketahanan pangan nasional adalah mengoptimalkan sumber pangan alternatif (diversifikasi pangan) selain beras, salah satunya adalah talas (Colocasia esculenta L.). Umbi talas bernilai gizi cukup tinggi, di antaranya mengandung karbohidrat, protein, vitamin B-kompleks, vitamin A, vitamin C, dan serat (Darkwa and Darkwa 2013, Sepulveda-Nieto et al. 2017, Wada et al. 2017). Talas sangat beragam di Indonesia; terdapat sekitar 180 kultivar, salah satunya adalah talas kultivar Kaliurang (Prana and Kuswara 2002). Talas Kaliurang telah lama dibudidayakan dan dikonsumsi oleh masyarakat di daerah Kaliurang, Yogyakarta, karena rasanya enak dan pulen, tanamannya toleran terhadap penyakit, dan tahan terhadap serangan hama. Namun pengembangan talas Kaliurang belum pernah ditangani secara serius (Prana and Kuswara 2002). Hal itu menjadikan talas memiliki peluang besar untuk dikembangkan dalam upaya diversifikasi pangan.

Untuk pengembangannya, talas Kaliurang memiliki kendala dalam penyediaan benih bermutu, baik benih generatif maupun vegetatif (Banjaw 2017). Benih unggul dapat diupayakan dengan melakukan perbaikan genetik, misalnya melalui induksi poliploid. Poliploidisasi pada talas Kaliurang secara in vitro telah dilakukan oleh Ermayanti et al. (2018) menggunakan kolkisin pada konsentrasi $0,05 \%, 0,1 \%$, dan $0,2 \%$ dengan waktu perendaman 1-3 hari. Percobaan tersebut menghasilkan talas Kaliurang tetraploid dengan jumlah kromosom $2 n=4 x=48$, yang berasal dari diploid dengan jumlah kromosom $2 n=2 x=$ 24. Hasil terbaik masing-masing konsentrasi yaitu (1) kolkisin $0,05 \%$ perendaman 1 hari menghasilkan $14,3 \%$ tunas tetraploid, (2) kolkisin $0,1 \%$ perendaman 1 hari menghasilkan 18,2\% tunas tetraploid (3) dan kolkisin $0,2 \%$ perendaman 3 hari menghasilkan $57,1 \%$ tunas tetraploid. Upaya perbaikan genetik ini diharapkan dapat menghasilkan tanaman dengan kualitas lebih unggul, yang juga mampu meningkatkan produktivitas tanaman.

Sejauh ini jumlah anakan talas Kaliurang yang tumbuh di lahan percobaan milik Pusat
Penelitian Bioteknologi, Lembaga IImu Pengetahuan Indonesia sedikit yaitu 1-2 anakan dalam kurun waktu yang lama hingga panen atau 9 bulan (data dari penelitian pendahuluan, tidak dipublikasikan) sehingga perlu dioptimalkan. Salah satu upaya perbanyakan tanaman adalah melalui perbanyakan in vitro. Perbanyakan dengan teknik kultur in vitro merupakan teknologi alternatif, yang memiliki keunggulan, di antaranya dapat menyediakan benih bermutu, seragam, dalam jumlah banyak, dan dalam waktu yang lebih singkat. Komposisi media untuk perbanyakan in vitro menjadi faktor penting dalam keberhasilan proses ini.

Komposisi media untuk setiap jenis tanaman tidak sama atau bersifat spesifik, karena genotipe dan kondisi fisiologi tanaman yang berbeda-beda (Lestari 2011). Zat pengatur tumbuh (ZPT) dan senyawa lain seperti vitamin yang tepat pada kultur in vitro diperlukan sehingga dapat menghasilkan planlet dalam jumlah banyak secara efisien. Penggunaan BAP dan beberapa senyawa lain pada media kultur dapat memacu proliferasi tunas karena adanya sinergisme antara senyawa tersebut (Lestari 2011). Salah satu zat pengatur tumbuh seperti benzylaminopurin (BAP) dan vitamin seperti tiamin dan adenin dapat memicu pertumbuhan tunas pada talas (Wulansari et al. 2014, Maretta et al. 2016). Adenin menentukan aktivitas sitokinin yang mendorong dalam pembelahan sel (Werner and Schmulling 2009), dan tiamin merupakan vitamin B1 yang dapat mempercepat pembelahan sel dan meningkatkan jumlah tunas (Bhojwani and Dantu 2013). Adenin berfungsi sebagai prekursor untuk sintesis sitokinin atau meningkatkan biosintesis sitokinin alami, dan bertindak secara sinergis dengan sitokinin yang dapat memacu proliferasi tunas (Naaz et al. 2014). Adenin adalah komponen dari enzim adenine phosphoribosyl transferase 1 yang merupakan enzim utama yang berperan dalam katalisis konversi sitokinin dari basa nitrogen (basa nukleo) menjadi nukleotida (Zhang et al. 2013). Hasil penelitian Khan et al. (2014) membuktikan bahwa penambahan adenin sulfat dan sitokinin jenis kinetin mampu meningkatkan proliferasi tunas stevia (Stevia rebaudiana). Wulansari et al. (2013) melaporkan bahwa penambahan 1 - $2 \mathrm{mg} \mathrm{L}^{-1}$ BAP dengan $1 \mathrm{mg} \mathrm{L}^{-1}$ tiamin dan $2 \mathrm{mg} \mathrm{L}^{-1}$ 
adenin secara in vitro meningkatkan laju multiplikasi tunas pada tiga kultivar talas yaitu Mentega, Bentul, dan Sutra. Sementara penelitian terkait konsentrasi tiamin dan adenin volume lainnya pada talas Kaliurang belum pernah dilaporkan.

Keberhasilan perbanyakan tanaman in vitro diukur dengan melihat kemampuan hidup planlet pada lingkungan luar (ex vitro) yaitu melalui proses aklimatisasi. Aklimatisasi adalah tahap penting untuk mengadaptasikan planlet hasil perbanyakan in vitro ke lingkungan luar dengan tujuan untuk mendapatkan benih tanaman yang siap ditanam di lapang. Selain itu, hasil perbanyakan in vitro talas Kaliurang tetraploid harus dikonfirmasi kembali untuk mengetahui stabilitas tingkat ploidinya secara berkala dari generasi ke generasi hingga diperoleh sejumlah tanaman tetraploid yang stabil. Penelitian ini bertujuan untuk mendapatkan media yang optimum untuk perbanyakan in vitro tunas tanaman talas Kaliurang diploid dan tetraploid dengan penambahan konsentrasi tiamin dan adenin dalam media dasar MS (Murashige and Skoog 1962) dan penambahan $2 \mathrm{mg} \mathrm{L}^{-1} \mathrm{BAP}$.

\section{BAHAN DAN METODE}

\section{Tempat dan waktu percobaan}

Penelitian ini dilakukan di Laboratorium Biak Sel dan Jaringan Tanaman dan Kebun Plasma Nutfah, Pusat Penelitian Bioteknologi, Lembaga IImu Pengetahuan Indonesia (LIPI), Cibinong. Penelitian dilaksanakan pada bulan Mei 2018 hingga Februari 2019.

\section{Rancangan percobaan dan analisis data

Percobaan ini dilaksanakan

menggunakan rancangan acak lengkap dengan enam ulangan. Perlakuan disusun secara faktorial $(4 \times 6)$, dengan faktor pertama adalah klon talas, yang terdiri dari empat klon talas Kaliurang $(\mathrm{K} 0=$ klon tetua Kaliurang diploid dan $\mathrm{K} 1, \mathrm{~K} 2$ dan $\mathrm{K} 3=$ klon Kaliurang tetraploid), dan faktor kedua adalah enam kombinasi konsentrasi tiamin dan adenin pada media perbanyakan tunas, yaitu sebagaimana disajikan pada Tabel 1 . Klon $\mathrm{K} 1$, K2, dan $\mathrm{K} 3$ ini merupakan hasil induksi poliploid oleh Ermayanti et al. (2018). K1 dihasilkan dari perlakuan perendaman dalam kolkisin $0,1 \%$ selama 1 hari; $\mathrm{K} 2$ dan $\mathrm{K} 3$, dari
Tabel 1. Perlakuan untuk perbanyakan in vitro talas Kaliurang dalam media dasar (MS+ 2 mg L BAP)

\begin{tabular}{|c|c|}
\hline Media Perlakuan & $\begin{array}{c}\text { Kode } \\
\text { Perlakuan }\end{array}$ \\
\hline $1 \mathrm{mg} \mathrm{L}^{-1}$ Tiamin $+2 \mathrm{mg} \mathrm{L}^{-1}$ Adenin & $\mathrm{T} 1 \mathrm{~A} 2$ \\
\hline $1 \mathrm{mg} \mathrm{L}^{-1}$ Tiamin $+4 \mathrm{mg} \mathrm{L}^{-1}$ Adenin & T1A4 \\
\hline $2 \mathrm{mg} \mathrm{L}^{-1}$ Tiamin $+2 \mathrm{mg} \mathrm{L}^{-1}$ Adenin & T2A2 \\
\hline $2 \mathrm{mg} \mathrm{L}^{-1}$ Tiamin $+4 \mathrm{mg} \mathrm{L}^{-1}$ Adenin & T2A4 \\
\hline $4 \mathrm{mg} \mathrm{L}^{-1}$ Tiamin $+2 \mathrm{mg} \mathrm{L}^{-1}$ Adenin & T4A2 \\
\hline $4 \mathrm{mg} \mathrm{L}^{-1}$ Tiamin $+4 \mathrm{mg} \mathrm{L}^{-1}$ Adenin & T4A4 \\
\hline
\end{tabular}

hasil perlakuan perendaman dalam kolkisin $0,05 \%$ selama 1 hari. Setiap satuan percobaan terdiri dari satu botol kultur yang masing-masing berisi dua eksplan. Data jumlah tunas per eksplan, jumlah daun, panjang petiol dan jumlah akar diamati setiap minggu hingga akhir minggu ke enam setelah penanaman eksplan (6 MST).

Analisis ragam untuk hasil pengamatan pada ketiga variabel dilakukan menggunakan perangkat lunak DSAASTAT (Dipartimento di Scienze Agrarie ed Ambiental Statistic) (Onofri and Pannacci 2014). Jika diperoleh data yang berbeda nyata, analisis dilanjutkan dengan uji Duncan Multiple Range Test (DMRT) pada taraf kepercayaan 95\%.

\section{Eksplan, media dan pemeliharaan kultur}

Eksplan yang digunakan adalah berupa bonggol (ukuran 1-2 cm) yang diperoleh dari stok tunas-tunas talas dari kultur in vitro empat klon talas Kaliurang yang didapat dari koleksi Laboratorium Biak Sel dan Jaringan Tanaman, Pusat Penelitian Bioteknologi, LIPI. Media kultur untuk perbanyakan tunas yang dicobakan menggunakan media MS (Murashige and Skoog 1962) yang ditambah dengan $2 \mathrm{mg} \mathrm{L}^{-1}$ BAP, $30 \mathrm{~g} \mathrm{~L}^{-1}$ sukrosa dan enam kombinasi konsentrasi tiamin dan adenin sebagaimana dicantumkan pada Tabel 1. Semua formulasi media yang dicobakan diatur pH-nya menjadi 5,8 kemudian ditambahkan $7 \mathrm{~g} \mathrm{~L}^{-1}$ bubuk agar sebagai pemadat. Sterilisasi media kultur dilakukan menggunakan autoclave. Semua kultur dipelihara dalam ruang kultur dengan suhu $25 \pm 2{ }^{\circ} \mathrm{C}$ dan intensitas cahaya 1000 1500 lux.

\section{Pengakaran tunas talas in vitro}

Tunas hasil perbanyakan in vitro, selanjutnya dipindahkan ke media pengakaran, yaitu media MS dengan 
setengah konsentrasi hara makro, tanpa ZPT, selama 4 minggu. Hal ini bertujuan untuk menginduksi perakaran, sebagai persiapan aklimatisasi.

\section{Aklimatisasi planlet}

Aklimatisasi dilakukan pada planlet, yakni tunas yang sudah memiliki akar. Tanaman dikeluarkan dari botol, dan dicuci bersih dengan menggunakan air kran, sampai tidak ada media yang tertinggal di akar tanaman. Tanaman ditanam pada media aklimatisasi, yang terdiri dari tanah steril, kokopit, dan sekam bakar, dengan perbandingan $1: 1: 1$ di dalam polibag berdiameter $8 \mathrm{~cm}$. Kemudian tanaman disungkup dengan menggunakan plastik transparan, dan diletakkan di rumah kaca. Sungkup plastik dibuka tahap demi tahap mulai minggu kedua sampai tanaman terlihat dapat bertahan tanpa sungkup. Persentase hidup tanaman dihitung pada minggu keenam.

\section{Konfirmasi stabilitas tingkat ploidi}

Talas Kaliurang hasil perbanyakan in vitro, pada umur 6 minggu setelah perlakuan (minggu terakhir pengamatan) dianalisis kembali tingkat ploidinya, menggunakan flositometer (BD Accuri C6 Plus). Analisis flositometri dilakukan pada dua sampel tanaman dari setiap perlakuan media secara acak. Potongan daun berukuran sekitar 0,5 $\mathrm{cm}^{2}$ diletakkan di atas cawan petri, ditetesi $250 \mu \mathrm{L}$ buffer cystain uv-ploidi, kemudian dicacah menggunakan silet hingga halus. Cacahan daun disaring (saringan milipor berukuran pori $30 \mu \mathrm{M}$ ), dan filtrat dimasukkan ke dalam tabung Eppendorf bervolume $2 \mathrm{~mL}$, lalu ditambahkan $600 \mu \mathrm{L}$ larutan pewarna flouresensi propidium iodida. Sampel dimasukkan ke dalam alat flositometer, dibaca pada panjang gelombang $440 \mathrm{~nm}$ dan kecepatan 1000 nukleus per detik. Sampel daun tanaman diploid digunakan sebagai pembanding. Rata-rata kandungan DNA dari tiap sampel ditunjukkan dengan histogram yang ditampilkan dan dibandingkan dengan hasil dari tanaman diploid.

\section{HASIL DAN PEMBAHASAN}

\section{Rata-rata jumlah tunas}

Inisiasi tunas dimulai dari minggu pertama hingga minggu terakhir pengamatan, yakni 6 MST. Terbentuknya tunas hasil
Tabel 2. Rata-rata dan kisaran jumlah tunas talas Kaliurang pada media dasar (MS $+2 \mathrm{mg} \mathrm{L}^{-1}$ $\mathrm{BAP}$ ) dengan berbagai kombinasi konsentrasi tiamin dan adenin pada umur 6 MST

\begin{tabular}{lcc}
\hline $\begin{array}{l}\text { Kode Media } \\
\text { Perlakuan }\end{array}$ & $\begin{array}{c}\text { Rata-Rata } \\
\text { Jumlah Tunas }\end{array}$ & $\begin{array}{c}\text { Kisaran } \\
\text { Jumlah Tunas }\end{array}$ \\
\hline T1A2 & $2,83^{\mathrm{ab}}$ & $0-6$ \\
T1A4 & $1,5^{\mathrm{b}}$ & $0-4$ \\
T2A2 & $1,67^{\mathrm{b}}$ & $0-4$ \\
T2A4 & $2,79^{\mathrm{ab}}$ & $0-5$ \\
T4A2 & $3,45^{\mathrm{a}}$ & $1-5$ \\
T4A4 & $1,70^{\mathrm{b}}$ & $1-4$ \\
\hline
\end{tabular}

Keterangan: Nilai yang diikuti oleh huruf yang sama menunjukkan tidak berbeda nyata berdasarkan uji DMRT dengan taraf kepercayaan $95 \%$

perbanyakan in vitro berkisar 1-6 tunas tiap eksplan. Untuk jumlah tunas, hasil analisis sidik ragam menunjukkan bahwa jenis media berpengaruh sangat nyata, sedangkan keempat klon yang diuji memberikan respon yang tidak berbeda. Oleh karena itu, data dianalisis kembali dengan RAL 1 faktor yaitu 6 media kombinasi tiamin dan adenin, semua klon dianggap sama (Tabel 2).

Media yang menghasilkan tunas terbanyak pada semua klon (diploid maupun tetraploid) adalah T4A2, yaitu dengan penambahan $4 \mathrm{mg} \mathrm{L}^{-1}$ tiamin dan $2 \mathrm{mg} \mathrm{L}^{-1}$ adenin pada media dasar $\mathrm{MS}+2 \mathrm{mg} \mathrm{L}^{-1} \mathrm{BAP}$. Media ini mampu menghasilkan jumlah tunas yang lebih baik dibandingkan lima media perlakuan lainnya, dengan rata-rata 3,45 tunas dengan kisaran 1-5 tunas. Media yang tergolong baik dalam menghasilkan jumlah tunas adalah T1A2 dan T2A4. Media yang menghasilkan jumlah tunas terendah adalah T1A4, T2A2, dan T4A4.

Pertumbuhan tunas mencapai maksimumnya pada minggu ke enam dan rata-rata mulai statis pada minggu tersebut (Gambar 1). Kurva ini menunjukkan bahwa pertumbuhan jumlah tunas pada media T4A2 terbaik untuk semua klon (K0: diploid dan K1, K2, K3: tetraploid). Kurva juga menunjukkan jumlah tunas pada tetraploid rata-rata lebih banyak dibandingkan diploid (K0). Rata-rata jumlah tunas yang dihasilkan talas tetraploid berkisar 3,33-3,67, sedangkan talas diploid rata-rata 3,17. Hal ini menunjukkan perbedaan karakter talas Kaliurang diploid dan tetraploid terlihat pada jumlah tunas tetraploid yang berjumlah lebih banyak dibandingkan diploidnya. Sehingga talas 
tetraploid berpotensi baik untuk dikembangkan, yaitu untuk mengatasi kendala penyediaan benih yang terjadi saat ini. Penampilan pertumbuhan tunas talas Kaliurang pada perbanyakan in vitro dapat dilihat pada Gambar 2.

Media dasar $\left(\mathrm{MS}+2 \mathrm{mg} \mathrm{L^{-1 }} \mathrm{BAP}\right)$
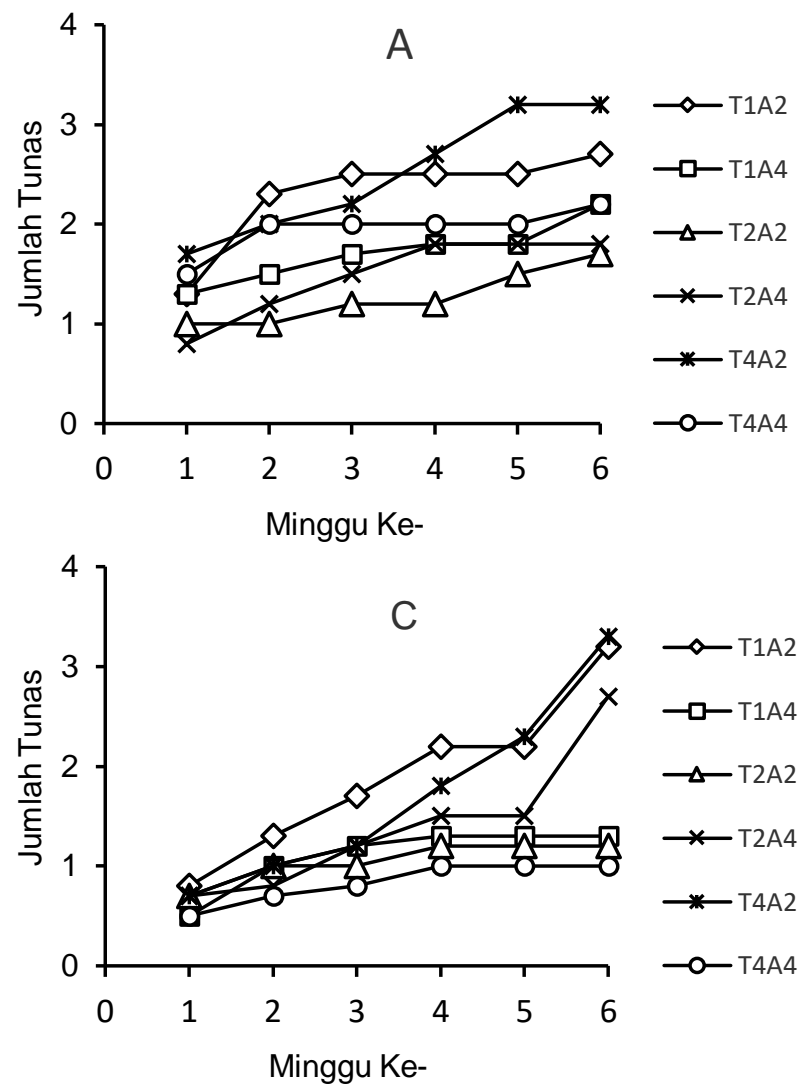

dengan penambahan $4 \mathrm{mg} \mathrm{L}^{-1}$ tiamin dan 2 $\mathrm{mg} \mathrm{L}^{-1}$ adenin (T4A2) juga berhasil menginduksi tunas $100 \%$ dibandingkan 4 perlakuan media lainnya. Hal ini menunjukkan, bahwa media tersebut merupakan media optimum untuk menghasilkan tunas talas Kaliurang, baik
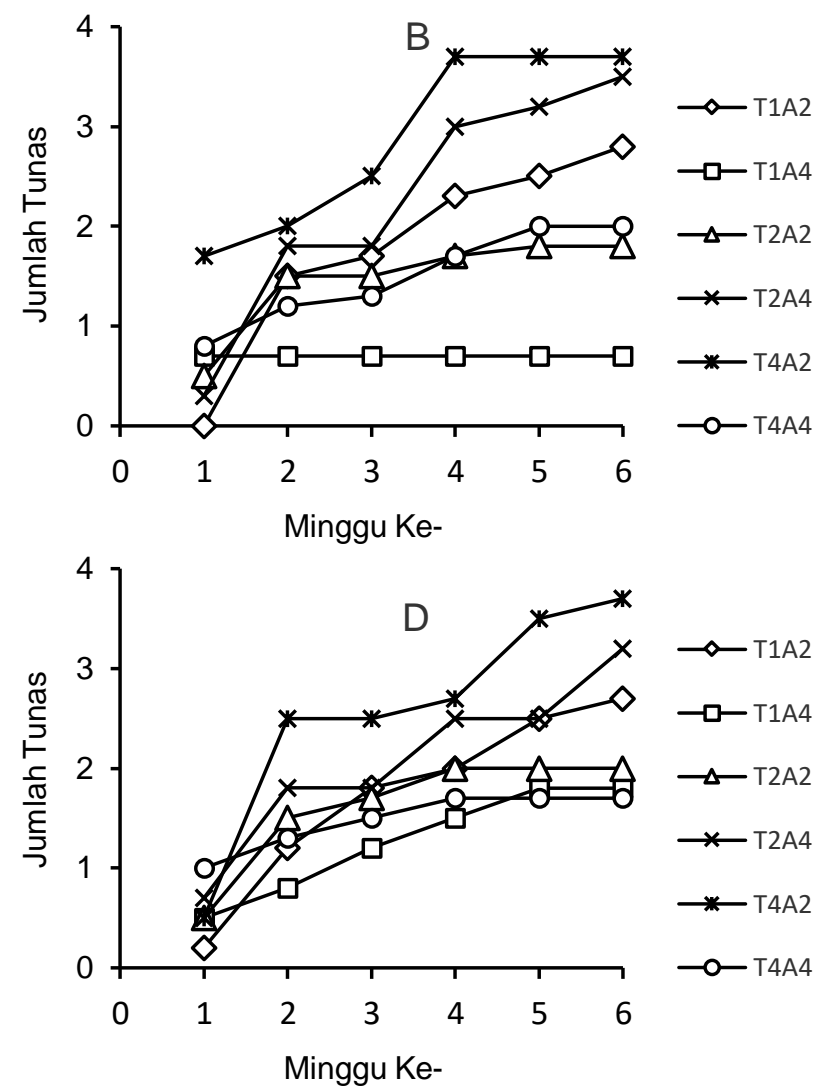

Gambar 1. Pertumbuhan jumlah tunas di media dasar (MS $\left.+2 \mathrm{mg} \mathrm{L}^{-1} \mathrm{BAP}\right)$ dengan perlakuan tiamin dan adenin selama 6 minggu. (A) Klon diploid K0, (B) klon tetraploid K1, (C) klon tetraploid K2, (D) klon tetraploid K3
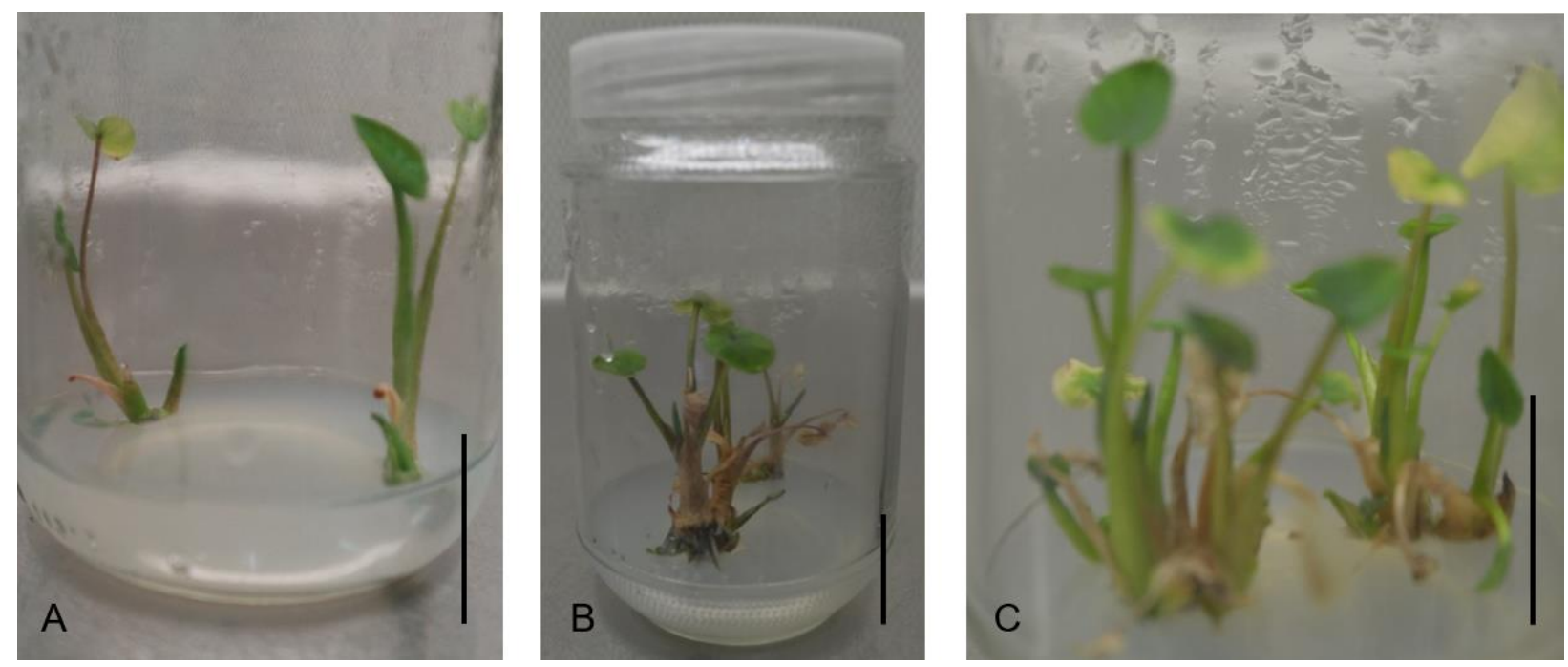

Gambar 2. Tunas talas Kaliurang pada media dasar (MS $+2 \mathrm{mg} \mathrm{L}^{-1} \mathrm{BAP}$ ) yang diberi perlakuan tiamin dan adenin. (A) tunas umur $1 \mathrm{MST}$, (B) umur 6 MST diploid, (C) umur 6 MST tetraploid. Garis skala $=2 \mathrm{~cm}$ 
diploid maupun tetraploid, secara in vitro. Pada proses pertumbuhan dan perkembangan jaringan, untuk memacu pembentukan tunas, dapat diberikan kombinasi ZPT dan vitamin. Interaksi antara keduanya di dalam media akan menjadi faktor pemicu pembentukan tunas. BAP, adenin dan tiamin diduga saling berinteraksi atau bekerjasama dalam menentukan pertumbuhan dan perkembangan eksplan.

Meningkatnya jumlah tunas disebabkan oleh adanya penambahan ZPT dari golongan sitokinin, yaitu BAP. BAP berfungsi untuk mendorong pembentukan, penggandaan, dan pertumbuhan tunas pada berbagai tanaman sehingga efektivitasnya tinggi untuk perbanyakan tanaman (Lestari 2011, Wulansari et al. 2014). Maretta et al. (2016) menyatakan bahwa penambahan $2 \mathrm{mg} \mathrm{L}^{-1}$ BAP meningkatkan jumlah tunas pada talas Satoimo. BAP merupakan komponen penting untuk proliferasi tunas in vitro (GrzegorczykKarolak et al. 2015). Adenin merupakan bentuk dasar dari sitokinin yang menentukan aktivitas sitokinin; penambahan adenin akan semakin meningkatkan aktivitas sitokinin. Sitokinin dapat mempengaruhi gen KNOX (Knotted Like Homeobox) yang menyandikan suatu protein yang berfungsi memacu pertumbuhan dan pemeliharaan meristem ujung batang, sehingga sel akan bersifat meristematik (Jasinski et al. 2005). Sel kemudian berdiferensiasi membentuk tunas. Sitokinin mendorong pembelahan sel dengan cara mengatur ekspresi gen tipe siklin $D$ $C y c D 3$, yang memiliki peran penting dalam mengatur transisi antara fase G1 ke S dalam siklus sel. Sitokinin mampu meningkatkan jumlah replikasi DNA yang terjadi selama siklus sel fase $S$ dan juga berperan dalam siklus sel fase $S$ dan juga berperan dalam mengatur transisi dari fase G2 ke M (Werner and Schmulling 2009). Penggunaan BAP dan adenin juga memberikan efek positif pada perbanyakan tunas beberapa tanaman, seperti kentang (Solanum tuberosum) (Singh et al. 2017), talas Jepang (C. esculenta) (Hattu et al. 2018), stevia (S. rebaudiana) (Khan et al. 2014), dan Swertia chirayita (Sharma et al. 2014).

Penambahan tiamin juga memiliki interaksi yang positif dengan sitokinin dalam meningkatkan pembentukan tunas (Bhojwani and Dantu 2013). Tiamin berfungsi sebagai koenzim, koenzim dari tiamin ini adalah
Tabel 3. Rata-rata dan kisaran jumlah daun talas Kaliurang pada media dasar (MS $+2 \mathrm{mg} \mathrm{L}^{-1}$ BAP) dengan berbagai kombinasi konsentrasi tiamin dan adenin pada 6 MST

\begin{tabular}{lcc}
\hline $\begin{array}{l}\text { Kode Media } \\
\text { Perlakuan }\end{array}$ & $\begin{array}{c}\text { Rata-Rata } \\
\text { Jumlah Daun }\end{array}$ & $\begin{array}{c}\text { Kisaran } \\
\text { Jumlah Daun }\end{array}$ \\
\hline T1A2 & $6,62^{\mathrm{ab}}$ & $1-16$ \\
T1A4 & $5,16^{\mathrm{ab}}$ & $1-11$ \\
T2A2 & $3,54^{\mathrm{b}}$ & $1-13$ \\
T2A4 & $6,45^{\mathrm{ab}}$ & $1-16$ \\
T4A2 & $7,62^{\mathrm{a}}$ & $1-18$ \\
T4A4 & $6,16^{\mathrm{ab}}$ & $1-11$ \\
\hline
\end{tabular}

Keterangan: Nilai yang diikuti oleh huruf yang sama menunjukkan tidak berbeda nyata berdasarkan uji DMRT dengan taraf kepercayaan $95 \%$

tiamin pirofosfat (TPP). TPP merupakan komponen penting yang dibutuhkan dalam aktivitas metabolisme, seperti biosintesis asetil-KoA dan asam amino, mengaktifkan siklus Krebs dan siklus Calvin (Du et al. 2011). TPP dibutuhkan saat dekarboksilasi oksidatif, dan memungkinkan masuknya substrat yang dapat dioksidasi ke dalam siklus Krebs, sehingga mengoptimalkan aktivitas respirasi untuk menghasilkan energi metabolisme tumbuhan (Iswari and Yuniastuti 2006). Wulansari et al. (2014) melaporkan bahwa penambahan $1 \mathrm{mg} \mathrm{L}^{-1}$ tiamin dan $2 \mathrm{mg}$ $\mathrm{L}^{-1}$ adenin mempengaruhi aktivitas BAP dalam meningkatkan jumlah tunas majemuk pada empat kultivar talas (C. esculenta).

\section{Rata-rata jumlah daun}

Semua media kultur rata-rata menunjukkan hasil yang baik dalam hal jumlah daun, meskipun jumlah daun yang dihasilkan sangat beragam, yaitu pada kisaran 1-18 daun untuk tiap tunasnya. Hasil analisis sidik ragam menunjukkan bahwa jenis media berpengaruh sangat nyata, sedangkan keempat klon yang diuji memberikan respon yang tidak berbeda terhadap jumlah daun. Pengaruh klon yang sama menyebabkan perlunya dilakukan analisis data kembali dengan RAL dengan faktor tunggal yaitu media perlakuan kombinasi tiamin dan adenin (Tabel 3). Media T4A2 memberikan jumlah daun terbanyak, dengan rata-rata 7,62 dengan kisaran 1-18 daun, diikuti oleh media T1A2, T2A4, T4A4, dan T1A4. Media yang menghasilkan jumlah daun terendah adalah T2A2. Umumnya 
Tabel 4. Rata-rata panjang petiol talas Kaliurang pada media dasar ( $\mathrm{MS}+2 \mathrm{mg} \mathrm{L}^{-1} \mathrm{BAP}$ ) dengan berbagai kombinasi konsentrasi tiamin dan adenin pada 6 MST

\begin{tabular}{lllll}
\hline \multirow{2}{*}{ Kode Media Perlakuan } & \multicolumn{4}{c}{ Rata-Rata Panjang Petiol (cm) Pada Klon } \\
\cline { 2 - 5 } & K0 & \multicolumn{1}{c}{ K1 } & K2 & $2,53^{\text {cde }}$ \\
\hline T1A2 & $2,38^{\text {cde }}$ & $2,71^{\text {bcde }}$ & $2,43^{\text {cde }}$ & $3,08^{\text {abcde }}$ \\
T1A4 & $1,97^{\mathrm{e}}$ & $3,15^{\text {abcd }}$ & $2,51^{\text {cde }}$ & $2,01^{\text {de }}$ \\
T2A2 & $3,32^{\text {abc }}$ & $2,28^{\text {cde }}$ & $2,75^{\text {bcde }}$ & $3,35^{\text {abc }}$ \\
T2A4 & $2,48^{\text {cde }}$ & $2,88^{\text {abcde }}$ & $2,73^{\text {bcde }}$ & $3,86^{\mathrm{a}}$ \\
T4A2 & $2,48^{\text {cde }}$ & $2,4^{\text {cde }}$ & $3,75^{\text {ab }}$ & $2,96^{\text {abcde }}$ \\
T4A4 & $1,95^{\mathrm{e}}$ & $2,93^{\text {abcde }}$ & $3,31^{\text {abc }}$ & \\
\hline
\end{tabular}

Keterangan: Nilai yang diikuti oleh huruf yang sama menunjukkan tidak berbeda nyata berdasarkan uji DMRT dengan taraf kepercayaan $95 \%$

jumlah daun yang dihasilkan setiap eksplan berkorelasi dengan jumlah tunas dari setiap eksplan. Semakin banyak jumlah tunas, jumlah daun juga semakin banyak, dan sebaliknya semakin sedikit jumlah tunas maka jumlah daun semakin sedikit.

\section{Rata-rata panjang petiol}

Hasil analisis sidik ragam untuk parameter panjang petiol menunjukkan adanya interaksi antara faktor jenis media dan klon (Tabel 4). Panjang petiol diukur untuk mewakili tinggi tanaman. Klon tetraploid K3 pada media T4A2 memiliki petiol terpanjang dengan nilai rata-rata $3,86 \mathrm{~cm}$. Klon diploid K0 pada media T1A4 dan T4A4 memiliki petiol terpendek, dengan nilai ratarata 1,97 dan $1,95 \mathrm{~cm}$.

Rata-rata panjang petiol tetraploid yaitu 2,82 $\mathrm{cm}$ sedangkan diploid $2,42 \mathrm{~cm}$. Hal ini menunjukkan bahwa talas Kaliurang tetraploid hasil perlakuan perendaman kolkisin $0,05 \%$ dan $0,1 \%$ mengalami perubahan sifat yaitu petiol menjadi lebih panjang. Hasil ini berbeda dengan yang didapatkan oleh Ermayanti et al. (2018) dalam penelitiannya, bahwa ukuran tanaman talas Kaliurang tetraploid hasil induksi dengan perendaman kolkisin pada awal generasi memiliki petiol yang lebih pendek dibandingkan diploidnya. Kristina and Syahid (2015) melaporkan bahwa pemberian kolkisin 0,05\% menjadikan tanaman lada memiliki jumlah daun dan ruas yang lebih pendek dan sedikit sehingga tanaman tampak lebih kecil. Tanaman Vicia villosa tetraploid hasil pemberian $0,005 \%$ kolkisin memiliki ukuran lebih pendek dan luas permukaan daun lebih besar dibandingkan diploidnya (Tulay and Unal 2010).
Tabel 5. Rata-rata dan kisaran jumlah akar talas Kaliurang pada media dasar (MS $+2 \mathrm{mg} \mathrm{L}^{-1}$ $\mathrm{BAP})$ dengan berbagai kombinasi konsentrasi tiamin dan adenin pada 6 MST

\begin{tabular}{lcc}
\hline $\begin{array}{l}\text { Kode Media } \\
\text { Perlakuan }\end{array}$ & $\begin{array}{c}\text { Rata-Rata } \\
\text { Jumlah Akar }\end{array}$ & $\begin{array}{c}\text { Kisaran } \\
\text { Jumlah Akar }\end{array}$ \\
\hline T1A2 & $0,87^{\mathrm{b}}$ & $0-4$ \\
T1A4 & $3,16^{\mathrm{ab}}$ & $0-11$ \\
T2A2 & $1,04^{\mathrm{b}}$ & $0-8$ \\
T2A4 & $0,375^{\mathrm{b}}$ & $0-2$ \\
T4A2 & $2,083^{\mathrm{b}}$ & $0-9$ \\
T4A4 & $5,25^{\mathrm{a}}$ & $0-13$ \\
\hline
\end{tabular}

Keterangan: Nilai yang diikuti oleh huruf yang sama menunjukkan tidak berbeda nyata berdasarkan uji DMRT dengan taraf kepercayaan $95 \%$

\section{Jumlah akar dan fase pengakaran}

Pada media perbanyakan tunas, beberapa tunas menumbuhkan akar, namun pertumbuhan akar tersebut sedikit dan lambat. Akar yang dihasilkan berwarna hijau kecoklatan. Hasil analisis sidik ragam menunjukkan bahwa hanya faktor jenis media yang berpengaruh terhadap jumlah akar, sehingga klon dianggap sama. Pengaruh faktor tunggal jenis media sangat nyata terhadap jumlah akar (Tabel 5).

Media yang menghasilkan jumlah akar terbaik adalah media T4A4, dengan rata-rata jumlah akar 5,25 (kisaran 0-13 akar), dan T1A4 dengan rata-rata 3,16 (kisaran 0-11 akar). Jumlah tunas yang berhasil membentuk akar hanya 50,7\% dari jumlah keseluruhan kultur (diploid dan tetraploid). Pada talas Kaliurang klon diploid, pertumbuhan akar lebih baik dibandingkan dengan klon tetraploid. Akar talas diploid muncul pada 1 hingga 4 MST, sedangkan pada tanaman tetraploid, akar tidak muncul hingga 6 MST (akhir pengamatan). 
Tunas yang sebagian besar tidak berakar menunjukkan bahwa media ini tidak efektif dalam menginduksi akar secara bersamaan dengan tahapan perbanyakan. Terhambatnya pertumbuhan akar pada media perbanyakan tunas dipengaruhi oleh penggunaan BAP, yang bersifat menghambat pengakaran. Menurut Hattu et al. (2018), penggunaan BAP dapat menghambat inisiasi, pemanjangan, dan perkembangan akar.

Salah satu faktor yang sangat menentukan keberhasilan aklimatisasi adalah perakaran planlet, sehingga sebelum tahap aklimatisasi diperlukan upaya agar semua tunas memiliki akar. Fase pengakaran dilakukan dengan memindahkan tunas ke media perakaran selama empat minggu, yaitu dengan menurunkan konsentrasi unsur hara makro dalam media MS menjadi setengahnya ( $1 / 2 \mathrm{MS})$, tanpa ZPT. Fase ini berhasil menginduksi akar $100 \%$ pada tunas yang sebelumnya belum berakar, dari semua media perlakuan perbanyakan in vitro tunas (Gambar 3). Media 1/2 MS mampu menghasilkan jumlah dan panjang akar yang lebih baik dibandingkan dengan media MS konsentrasi penuh (Sarropoulou et al. 2015).

\section{Persentase keberhasilan aklimatisasi}

Pasca-aklimatisasi, perbedaan tanaman talas Kaliurang diploid dan tetraploid terlihat pada panjang petiol. Talas kaliurang diploid memiliki petiol yang lebih panjang dibandingkan tetraploid (Gambar 4). Keberhasilan perbanyakan in vitro tanaman dapat diukur dengan melihat kemampuan hidup tanaman pada lingkungan ex vitro melalui aklimatisasi. Tahapan aklimatisasi tidak menemui kendala pada penelitian ini, tanaman dapat bertahan hidup dengan cukup baik, yaitu mencapai 99,1\%. Hal ini menunjukkan bahwa hasil perbanyakan tunas in vitro pada media dasar (MS $+2 \mathrm{mg}$ $\mathrm{L}^{-1} \mathrm{BAP}$ ) yang diberi penambahan tiamin dan adenin mampu menghasilkan kualitas tunas yang bermutu, sehingga keberhasilan hidup planlet talas Kaliurang pada lingkungan ex vitro cukup tinggi, baik untuk tanaman diploid maupun tetraploid (Gambar 4).

Umumnya tanaman hasil mutasi baik secara kimia maupun fisik memiliki kendala pada tahap aklimatisasi, seperti kemampuan hidup yang masih rendah, tanaman tidak tegar, dan pertumbuhan abnormal. Azmi et al. (2016) melaporkan, bahwa tanaman Anggrek (Phalaenopsis amabilis) hasil induksi mutasi menggunakan kolkisin menunjukkan pertumbuhan abnormal, yaitu daun tidak

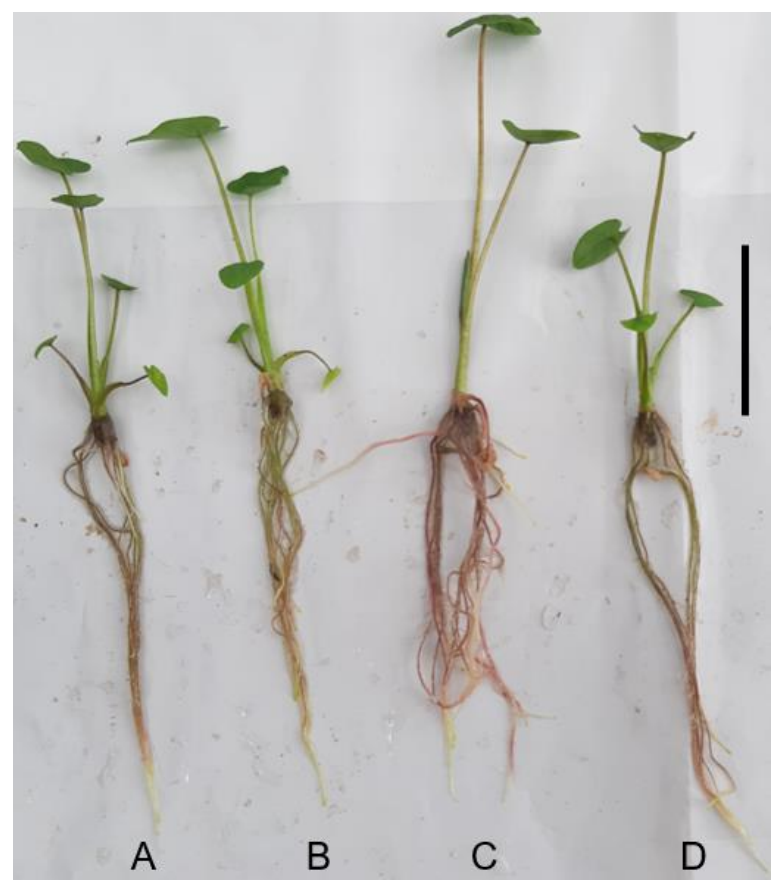

Gambar 3. Akar talas Kaliurang yang terbentuk pada media perakaran berupa setengah konsentrasi hara makro pada media MS tanpa ZPT. (A) klon diploid K0, (B) klon tetraploid K1, (C) klon tetraploid K2, (D) klon tetraploid K3. Garis skala $=5 \mathrm{~cm}$
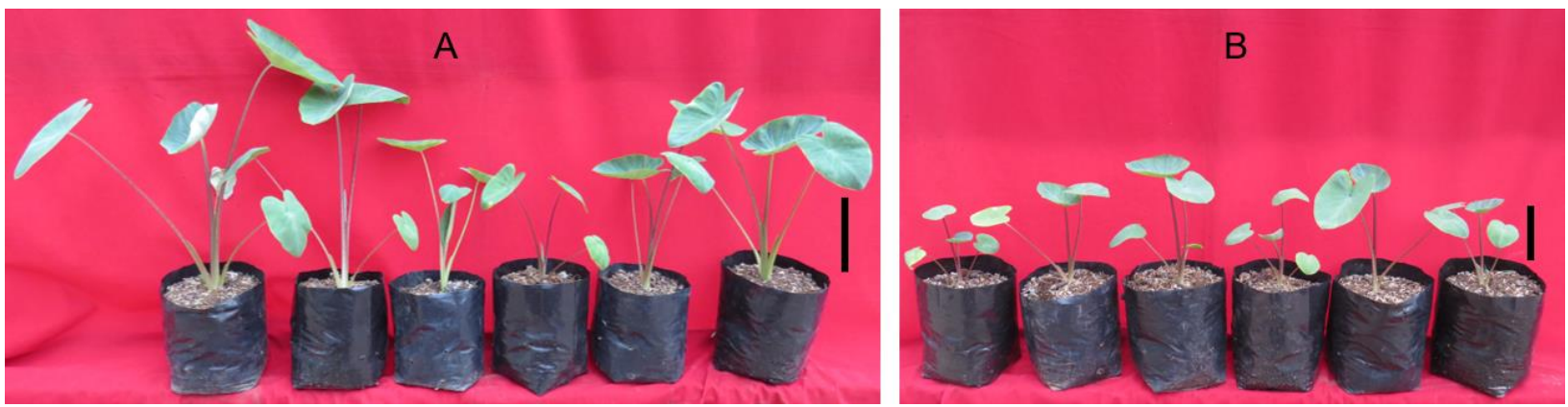

Gambar 4. Aklimatisasi tunas in vitro talas Kaliurang diploid (klon K0, diploid). (A) diploid, (B) tetraploid. Garis skala $=15 \mathrm{~cm}$ 
tumbuh dan protokorm yang berakar. Kemampuan hidup stevia (S. rebaudiana Bert) Klon BS, hasil perlakuan kolkisin, menunjukkan kemampuan hidup yang rendah, yaitu berkisar 11,78-43,19\% (Sinta 2018). Namun dengan induksi pertumbuhan akar,
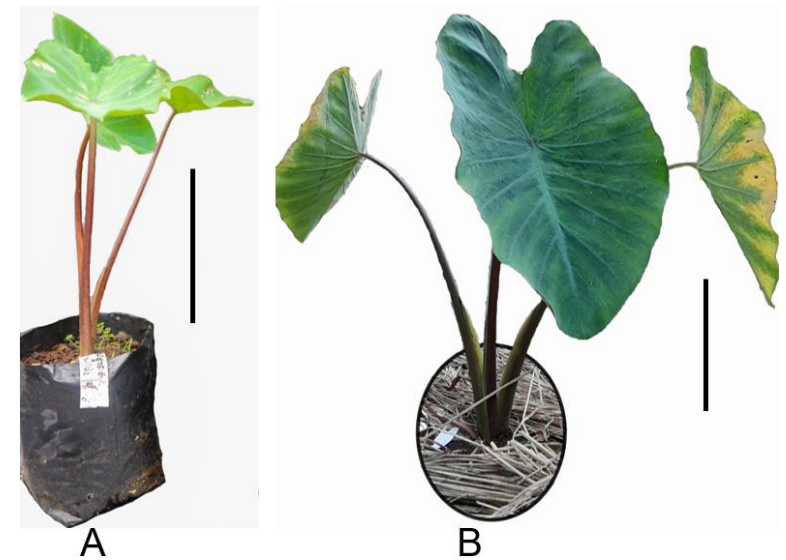

Gambar 5. Pertumbuhan talas Kaliurang tetraploid. (A) 6 MST penanaman di lath house (pascaaklimatisasi I) dan (B) 6 MST penanaman di lapang (pasca-aklimatisasi II). Garis skala $=20 \mathrm{~cm}$
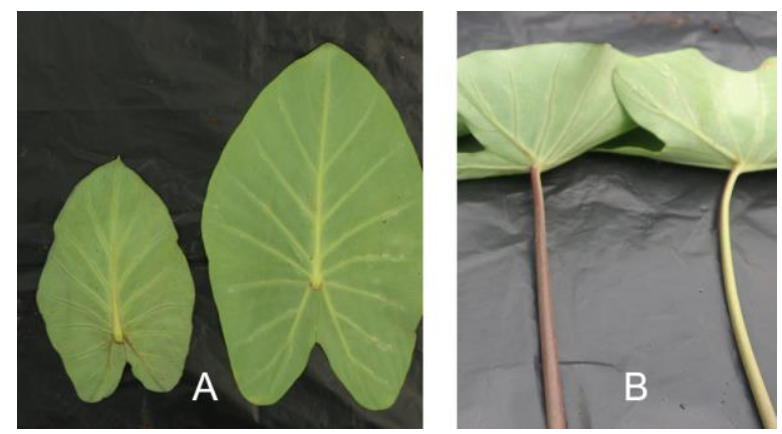

Gambar 6. Perbedaan karakter talas Kaliurang diploid (kanan) dan tetraploid (kiri) pada umur 4 minggu setelah penanaman di lapangan, (A) warna tulang daun (diploid hijau, tetraploid ungu), (B) warna petiol (diploid hijau, tetraploid ungu)
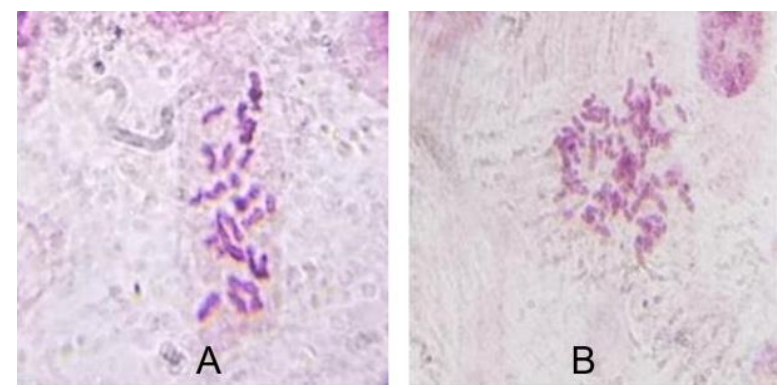

Gambar 7. Jumlah kromosom hasil pengamatan dengan metode squashing dari akar talas Kaliurang dengan perbesaran 400 1000x. (A) diploid, (B) tetraploid hasil penelitian Ermayanti et al. 2018 planlet talas Kaliurang tetraploid dapat mempertahankan kemampuan hidup yang tinggi pada fase aklimatisasi. Talas Kaliurang diploid dan tetraploid, setelah 6 minggu aklimatisasi, memperlihatkan pertumbuhan yang baik dengan daun yang berwarna hijau segar. Pasca-aklimatisasi, tanaman ditanam di lath house dan kemudian dipindahtanam ke lahan. Tanaman tersebut tetap menunjukkan pertumbuhan yang baik (Gambar 5).

Talas Kaliurang tetraploid memiliki perbedaan karakter yang terlihat pada tanaman pasca aklimatisasi. Talas tetraploid memiliki karakter lebar daun yang lebih lebar, panjang daun yang lebih pendek dibandingkan diploidnya, tulang daun dan petiol tetraploid berwarna ungu sedangkan diploid berwarna hijau (Gambar 6).

\section{Konfirmasi stabilitas ploidi}

Talas Kaliurang tetraploid dari hasil induksi poliploid kemungkinan memiliki jumlah ploidi yang belum stabil pada beberapa
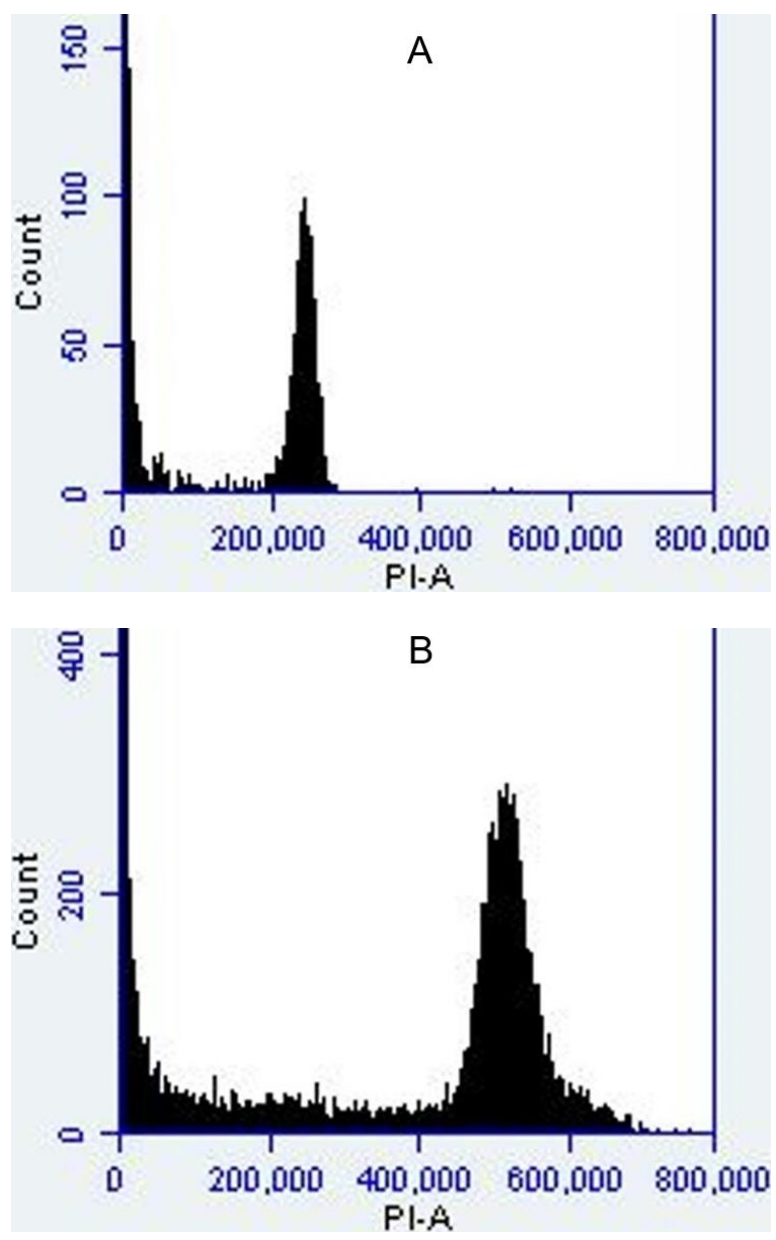

Gambar 8. Histogram flositometer tunas talas Kaliurang untuk konfirmasi tingkat ploidi. (A) diploid, (B) tetraploid 
generasi, sehingga diperlukan konfirmasi ulang tingkat ploidi pada tunasnya secara berkala. Hal ini bertujuan untuk mengetahui stabilitas ploidi tanaman pada generasi berikutnya, setelah mengalami proses perbanyakan in vitro, dengan perlakuan tiamin dan adenin. Jumlah kromosom talas Kaliurang (Gambar 7) adalah $2 n=2 x=24$ (diploid) dan $2 \mathrm{n}=4 \mathrm{x}=48$ (tetraploid), dengan jumlah kromosom dasar Colocasia yaitu $\mathrm{x}=12$ dan $\mathrm{x}$ $=14$ (Ermayanti et al. 2018). Analisis tingkat ploidi dengan flositometri pada tunas in vitro hasil perbanyakan menunjukkan tingkat ploidi yang sama dengan tunas kontrol (sebelum diberi perlakuan perbanyakan in vitro). Hal ini menyatakan bahwa tingkat ploidi tunas talas Kaliurang dari hasil perendaman kolkisin, telah stabil. Beberapa contoh histogram hasil konfirmasi dengan flositometer ditampilkan pada Gambar 8.

\section{KESIMPULAN}

Media optimum untuk perbanyakan in vitro tunas talas Kaliurang diploid dan tetraploid adalah media dasar (MS $+2 \mathrm{mg} \mathrm{L}^{-1}$ BAP) dengan penambahan $4 \mathrm{mg} \mathrm{L}^{-1}$ tiamin dan $2 \mathrm{mg} \mathrm{L}^{-1}$ adenin (jumlah tunas yang berhasil diinduksi mencapai 5 tunas). Media pengakaran yang berupa media MS dengan setengah konsentrasi hara makro, tanpa ZPT, berhasil menginduksi akar 100\%. Persentase hidup talas Kaliurang diploid dan tetraploid pada fase aklimatisasi cukup tinggi, yaitu mencapai $99,1 \%$. Stabilitas ploidi talas Kaliurang tetraploid dari hasil perbanyakan in vitro tetap terjaga (stabil).

\section{UCAPAN TERIMA KASIH}

Ucapan terima kasih ditujukan kepada Ibu Dr. Tri Muji Ermayanti dari Laboratorium Biak sel dan Jaringan Tanaman, Pusat Penelitian Bioteknologi, Lembaga IImu Pengetahuan Indonesia (LIPI) Cibinong atas diskusi, saran dan masukan pada penelitian ini. Ucapan terimakasih juga disampaikan kepada Bapak Erwin Al Hafiizh, MSi atas bantuannya dalam menganalisis kestabilan ploidi dengan flositometer.

\section{DAFTAR PUSTAKA}

Azmi TKK, Sukma D, Aziz SA, Syukur M (2016) Polyploidy induction of moth orchid (Phalaenopsis amabilis (L.) Blume) by colchicine treatment on pollinated flowers. J Agric Sci Sri Lanka 11: 62-73. doi: 10.4038/jas.v11i2.8118

Banjaw DT (2017) Review of taro (Colocasia esculenta) genetics and breeding. J Hortic 4: 196. doi: 10.4172/23760354.1000196

Bhojwani SS, Dantu PK (2013) Plant tissue culture: An introduction text. Springer, New Delhi. doi: 10.1007/978-81-3221026-9

Darkwa S, Darkwa AA (2013) Taro "Colocasia esculenta": It's utilization in food products in Ghana. J Food Process Technol 4: 225 . doi: 10.4172/21577110.1000225

Du Q, Wang H, Xie J (2011) Thiamine (vitamin B1) biosynthesis and regulation: $A$ rich source of antimicrobial drug targets? Int J Biol Sci 7: 41-52. doi: 10.7150/ijbs.7.41

Ermayanti TM, Wijayanta AN, Ratnadewi D (2018) Induksi poliploidi pada tanaman talas (Colocasia esculenta (L.) Schott) kultivar kaliurang dengan perlakuan kolkisin secara in vitro. J Biol Indones 14: 91-102. doi: 10.14203/jbi.v14i1.3667

Grzegorczyk-Karolak I, Kuzma L, Wysokinska $H$ (2015) The effect of cytokinins on shoot proliferation, secondary metabolite production and antioxidant potential in shoot cultures of Scutellaria alpina. Plant Cell Tiss Organ Cult 122: 699-708. doi: 10.1007/s11240-0150804-5

Hattu W, Parera DF, Raharjo SHT (2018) Penggunaan adenin sulfat pada perbanyakan mikro talas Jepang. Agrologia 7:59-70. doi: 10.30598/a.v7i2.763

Iswari RS, Yuniastuti A (2006) Biokimia. Graha IImu, Yogyakarta

Jasinski S, Piazza P, Craft J, Hay A, Woolley L, Rieu I, Phillips A, Hedden P, Tsiantis M (2005). KNOX action in Arabidopsis is mediated by coordinate regulation of cytokinin and gibberellin activities. Curr Biol 15: 1560-1565. doi: 10.1016/j.cub.2005.07.023

Khan MK, Misra P, Sharma T, Shukla PK, Ramteke PW (2014) Effect of adenine sulphate on in vitro mass propagation of Stevia rebaudiana Bertoni. J Med Plant Res 8: 543-549. doi: 10.5897/JMPR2013.5217

Kristina NN, Syahid SF (2015) Pengaruh 
kolkhisin terhadap penampilan lada (Piper nigrum L.) mutan dan analisis ploidi. J Littri 21: 125-130. doi: 10.21082/littri.v21n3.2015.125-130

Lestari EG (2011) Peranan zat pengatur tumbuh dalam perbanyakan tanaman melalui kultur jaringan. J AgroBiogen 7: 63-68. doi: 10.21082/jbio.v7n1.2011.p63-68 Maretta D, Handayani DP, Rosdayanti $H$, Tanjung A (2016) Multiplikasi tunas dan induksi umbi mikro satoimo (Colocasia esculenta L. Schott) pada beberapa konsentrasi sukrosa dan benzilaminopurin. J Bioteknol Biosains Indones 3: 81-88. doi: 10.29122/jbbi.v3i2.150

Murashige T, Skoog F (1962) A revised medium for rapid growth and bio assays for tobacco tissue cultures. Physiol Plant 15: 473-497. doi: 10.1111/j.13993054.1962.tb08052.x

Naaz A, Shahzad A, Anis M (2014) Effect of adenine sulphate interaction on growth and development of shoot regeneration and inhibition of shoot tip necrosis under in vitro condition in adult Syzygium cumini L.-A multipurpose tree. Appl Biochem Biotechnol 173: 90-102. doi: 10.1007/s12010-014-0797-2

Onofri A, Pannacci E (2014) Spreadsheet tools for biometry classes in crop science programmes. Commun Biometry Crop Sci 9: 43-53

Prana MS, Kuswara T (2002) Budidaya Talas: Diversifikasi untuk menunjang ketahanan pangan nasional. Medikom Pustaka Mandiri, Jakarta

Sarropoulou V, Dimassi-Theriou K, Therios I (2015) Medium strength in inorganics and PVP concentration effects on cherry rootstocks in vitro rooting. Hort Sci (Prague) 42: 185-192. doi: 10.17221/359/2014-hortsci

Sepulveda-Nieto MDP, Bonifacio-Anacleto F, de Figueiredo CF, de Moraes-Filho RM, Alzate-Marin AL (2017) Accessible morphological and genetic markers for identification of taioba and taro, two forgotten human foods. Horticulturae 3: 49. doi: 10.3390/horticulturae3040049

Sharma V, Kamal B, Srivastava N, Dobriyal AK, Jadon VS (2014) In Vitro flower induction from shoots regenerated from cultured axillary buds of endangered medicinal herb Swertia chirayita $\mathrm{H}$.
Karst. Biotechnol Res Int 2014: 264690. doi: 10.1155/2014/264690

Singh AK, Sharma MK, Chaudhary R, Sengar RS (2017) Effects of BAP and adenin sulphate on shoot regeneration from callus in potato (Solanum tuberosum L.). Biotech Today 7: 49-51. doi: 10.5958/2322-0996.2017.00006.0

Sinta MM (2018) Induksi mutasi stevia (Stevia rebaudiana Bert) Klon BS dengan kolkisin untuk meningkatkan kandungan steviosida dan rebaudiosida-A. Tesis, Institut Pertanian Bogor

Tulay E, Unal M (2010) Production of colchicine induced tetraploids in Vicia villosa roth. Caryologia 63: 292-303. doi: 10.1080/00087114.2010.10589739

Wada E, Asfaw Z, Feyissa T, Tesfaye K (2017) Farmers perception of agromorphological traits and uses cocoyam (Xanthosoma sagittifolium (L.) Schott) grown in Ethiopia. Afr J Agric Res 12: 2681-2691. doi: 10.5897/AJAR2017.12465

Werner T, Schmulling T (2009) Cytokinin action in plant development. Curr Opin Plant Biol 12: 527-538. doi: 10.1016/j.pbi.2009.07.002

Wulansari A, Martin AF, Ermayanti TM (2014) Peningkatan multiplikasi tunas beberapa aksesi talas Indonesia menggunakan tiamin dan adenin serta preservasinya secara in vitro pada suhu rendah. Prosiding Seminar Nasional: Hasil Penelitian Unggulan Bidang Pangan Nabati. Bogor 25 September 2014. hal 355-365. doi: 10.13140/RG.2.1.5090.6647

Wulansari A, Martin AF, Rantau DE, Ermayanti TM (2013) Perbanyakan beberapa aksesi talas (Colocasia esculenta L.) diploid secara kultur jaringan dan konservasinya mendukung diversifikasi pangan. Prosiding Seminar Nasional Riset Pangan, Obat-obatan dan Lingkungan untuk Kesehatan. Bogor 27-28 Juni 2013. hal 11-19. ISBN: 978-602-14503-1-4

Zhang X, Chen Y, Lin X, Hong X, Zhu Y, Li W, He W, An F, Guo H (2013) Adenine phosphoribosyl transferase 1 is a key enzyme catalyzing cytokinin conversion from nucleobases to nucleotides in Arabidopsis. Mol Plant 6: 1661-1672. doi: $10.1093 / \mathrm{mp} / \mathrm{sst071}$ 